\title{
Images of Power in the Societies of Antiquity and the Middle Ages: Symbols and Ritual Practices of the East and West
}

\author{
Evgueny Alexandrovich Chiglintsev ${ }^{1}$, Natalya Yurievna Bikeyeva ${ }^{1}$, Maxim Vadimovich Griger $^{1}$, Igor \\ Vladimirovich Vostrikov ${ }^{1}$, Farit Nafisovich Ahmadiev ${ }^{1}$, Alexandr Alexandrovich Zaitsev ${ }^{1}$, Natalia Anatolievna \\ Shadrina $^{1} \&$ Enzhe Midhatovna Dusaeva ${ }^{1}$ \\ ${ }^{1}$ Kazan Federal University, Russia \\ Correspondence: Evgueny Alexandrovich Chiglintsev, Kazan Federal University, Russia. E-mail: info@ores.su
}

Received: June 9, 2019

doi:10.5539/jpl.v12n5p83
Accepted: August 25, $2019 \quad$ Online Published: August 31, 2019

URL: https://doi.org/10.5539/jpl.v12n5p83

\begin{abstract}
This collective article is dedicated to the images of power in the ancient and medieval societies, their forming, functions and the ways of representation. Authors found the universal components of the images of power in the different pre-industrial societies of the East and Vest, such as procedures of obtaining power, coronation and anointment, ruler's regalia and the forms of organizing space of power. The authors investigate the relationship between the secular and the sacred elements in the political mythology of power. This paper deals with the evolution of images of power, rituals and symbols of authority from Ancient Eastern to Medieval societies. The purpose of the article is to present the universal components of the images of power in Ancient and Medieval times. The identification of common and specific features in the representation of power and ritual practices will allow us to see the evolution of ideas about power in pre-industrial societies.
\end{abstract}

Keywords: authority, image of power, rulers, symbols and rituals of power

\section{Introduction}

The study of the problem of power in the history of mankind continues to be one of the key directions of modern social sciences. Power is primarily an image that is maintained in the public mind. Therefore, the representation of power, that is, its communicative component, is a key condition for its existence.

The history of the countries of East and West in Antiquity and the Middle Ages suggests synthesis phenomena in the formation of the image of power. But the correlation in this synthesis of interacting cultures is a scientific problem in itself. From this point of view, modern historiography studies the symbolism of rule in the power of Alexander the Great and his successors. We denote Alexander's policy by the concept of "orientalism" introduced by E. Said, but we interpret it as a set of actions to borrow Persian traditions in order to represent the new throne in front of the conquered population of the East.

\section{Methods}

Proceeding from the hermeneutic (communicative) variant of cognition of social reality, power is perceived as a sociocultural construct, formed via the meanings that are created, conceptualized and accepted by members of this social community. One of the key concepts of power is an authority of the individual, recognized by community members and understood by them. At the same time, social construction embraces representations of roles in the system of domination - submission via texts, signs and symbols that have survived to this day and are decipherable. Such roles symbolically reflect the social order in its entirety and are of great strategic importance, representing the integration of all institutions in a meaningful world. And the most important function of power is manifested in this symbolic representation of the institutional order.

The reference to the symbolism of power is based on the methodological foundations of political anthropology, which in the 1960s has become a respectable branch of humanitarian knowledge which concerns the evolution of human political life in a historical context. In the 1970-80s, with the help of its methods, all pre-industrial societies were studied, and today political anthropology refers to the analysis of rituals and symbols in the modern political culture of Europe. 
The authors used the comparative historical method, as well as the method of analogies, which made it possible to identify common and specific features in the evolution of the institutions of power and rituals throughout Antiquity and the Middle Ages, as well as in their representation through symbols and signs.

The study comprehensively uses narrative, visual, and linguistic sources, as well as special methods. The earliest source being attracted was Books of Samuel. It not only describes the early period of biblical history, which some scholars consider unreliable, but also reflects the formation of throne, presents the figure of David as a model for subsequent kings and monarchs of medieval Europe. Among the narrative sources that provide information about the system of power, its attributes and ritual practices of Antiquity and the Middle Ages are the works of ancient authors, Late Antique Roman and Byzantine writers, medieval Christian works, Mongolian and Persian sources. Works that required a comprehensive study include illustrations from Commentary on the Apocalypse by St. Beatus of Liébana, a monk and theologian of the 8th century, preserved in later manuscripts.

\section{Results and Discussion}

\subsection{The Ruler: Gaining Power and Clothing Symbology}

Ancient Jews revealed the symbolism of empowerment already at an early stage in the formation of the state. The institute of reign, according to our source, has already been formed in other cultures of the Ancient East. The people are asking prophet Samuel instead of the previous authority of the heads of the houses and elders, leaders (judges) and prophets to let him have the ruler to judge, as he did for other nations (1 Sam. 8: 5). But there is no reference to symbols in the text: the emperor's's power is exposed through functions, and the main one is leadership in the war (1 Sam. 8:20). Since only God really has power over Israel, authority is delegated to the ruler through the ritual of anointing (1 Sam 10: 1). Apparently, during the formation of the state among Jewish tribes, the symbolism of royal power was common to the entire region and was of little interest to the author of biblical books.

We find the formed ritual of clothing the ruler with power in the traditions of the nomadic empires of Central Asia. Moreover, hadover of power is not only sanctioned by the gods, but also carefully organized by the rulers themselves. Thus, the hereditary power right of the sons and grandsons of Genghis Khan along with divine sanction was necessarily confirmed by society: under pain of death, it was forbidden to self-proclaim emperor without permission, if there was no decision of the kurultai. The ritual was the following: the successor of the first Mongolian kagan was his son Ogedei, who gained the highest power in 1227 according to the will of his father; but since he was the youngest of the contenders, his statement was connected with the obligatory ritual support ceremony in Kurultai; and when one of the following khans was elected, Mengue (1251), a ritual attempt to renounce power was present at the ceremony until he again declared his support for the kurultai (Jovaini. I, 29; III, $3)$.

\subsection{The Crown as a Symbol of Power}

The eastern rulers had the tradition to use royal jewelry from ancient times. So the Amalekite, who killed King Saul, took off his crown (nezer - נצערדה - אצrist), i.e. bracelet (2 Sam 1:10). The practice of wearing the crown was also generalized among other Semitic kings: thus, having captured Rabbi of Ammon, David took the golden crown decorated with a precious stone (ateret - עטרת) of the local king and put it on his head (2 Sam 12:30).

The process of empowering the people even in democratic Greek policies takes on a unique form of coronation. In the museum of the Athenian agora there are reliefs symbolically depicting the handing of power to an anthropomorphic character personifying the demos, namely in the form of laying on his head a symbol of powerthe crown. In the empire of Alexander, the tiara and the diadem are symbolically burdened with the image of power. In the Achaemenid empire, the straight tiara was royal regalia (Xen. Cyrop. VIII. 3.13; Plut. De Frat. amor., 18) and, apparently, the king could wear the tiara with the diadem. Narrative sources mention only the diadem, not the tiara. Only Plutarch indicates the fact that Alexander refused the tiara (Plut. Alex. 45. 1-2). However, on some coins, Alexander is depicted in the tiara, which may be evidence of his borrowing this royal regalia. Perhaps Alexander used it only in front of the eastern subjects. Before Alexander, the diadem in the Achaemenid empire could be worn as an attribute not only by the king, but also by his relatives, the highest nobility (Xen. Cyr. VIII. 3.13). Alexander's use of the diadem as royal regalia is beyond doubt. In particular, Arrian cited an episode when the wind blew off the diadem from Alexander's head (Arr. Anab. VII. 22. 2); Plutarch narrated the case when a certain Dionysius sat on the royal throne in royal attire and diadem (Plut. Alex. 73. 3-4); and after the death of Alexander, the diadem along with his clothes, weapons, the ring was also mentioned (Curt. 10. 6. 4). 
Late Antique authors point to purple clothing and a diadem (crown) as the main symbols. However, written and archaeological evidence of this is not enough, and there are practically no data on barbaric insignia. The use of Roman type signs by barbarian rulers is reported by Gregory of Tours. Clovis, took the title of consul, and "tunica blattea indutus et clamide, inponens vertice diademam". (Greg. Tur. Lib. Hist. II. 38). We find a similar description, but without signs of authority, in Jordan: the emperor Zeno demised "insigne regio amictu, quasi iam Gothorum Romanorumque regnator" to the ruler of the Ostrogoths, Theodoric (Iordanis. De origine actibusque getarum. LVII. 295). Representation systems of power of the rulers of the 5th-6th centuries were built accordin to imperial patterns. In the developed Middle Ages, the royal and imperial coronation became the most important element in the establishment of every new emperor on the throne, combining the Byzantine and Roman elements, appealing to the Old Testament tradition and acquiring a clearly sacred character.

Paradoxically, the significance of the crown as a symbol of power is well illustrated by the loss of the imperial crown by Frederick II Staufen, an event that an eyewitness Franciscan monk Salimbene (1221 - 1289) described in his Chronicle. Frederick II had been crowned many times (as king of Sicily, king of the Romans and as emperor). He was famous for many victories, but in 1248 the besieged Parmians and their allies made a successful sortie out, destroyed the fortified camp of Frederick II, captured prisoners, treasury, jewelry and the crown of the emperor.

\subsection{Sacralization of the Space of Power}

The endowment of the ruler and his attributes with sacred power always existed in Antiquity and the Middle Ages, but especially in attempts by the authorities to politically unite peoples. At first, new leaders, deprived of insignia, looked like foreign in the world that arose on the ruins of the Roman Empire, but gradually the symbolic representation of their dominant practices grew. Roman authors deprive the images of barbarian rulers of the sacredness, which reflects the general tendency of the development of the image of power in Antiquity and the Middle Ages. With the creation of the developed administrative apparatus, the approval of the king "legitimate authority for decision-making", the need for a sacred ruler disappeared, but special respect for him remained, manifested in speech etiquette, ceremonial, attribution, sacred functional meaning of which has already been lost.

On the Iberian Peninsula, within the framework of the interaction of the Arab-Berber Muslim culture of the south and the Christian culture of the north of Spain, Christian artists borrowed Muslim images of power intuitively. Mosarabs reflected the synthesis trends characteristic of the culture of this region in the 8th-15th centuries. In the context of the Mozarabic tradition, this refers more to symbiosis, layering of the elements of different origin, which manifests itself in a special style of manuscripts. Islamic influence is evident here.

In medieval Christian culture, the figure of Christ personifies the supreme power, the king of kings. So, in a miniature depicting the scene of the Last Judgment from the manuscript of the 10th century Beatus Escorial, Christ is pictured sitting cross-legged on a cloud resembling a lush pillow, which refers the viewer to the Muslim visual tradition. The influence is traced here not in the semantic, but in the formal terms. Authors add Muslim features to secular rulers: on the pages of Morgan Beatus (960s), the Babylonian Harlot appears in a crown decorated with an inverted crescent moon and sitting in a special pose on pillows instead of the throne, the usual Christian tradition.

In the days of the Republic, this attribute, "painful" and "hated" to citizens, could be used by rulers only "for the veneration of the gods" (Dion. Halic. IV, 74, 1-2) or as a symbol of victory over the enemy during triumph.

In Franciscan hagiography and iconography, the throne embodies the idea of power, not physical, but spiritual, symbolically referring to the image of Christ. In hagiography, the throne is present in the plot of the vision of thrones, emphasizing the status of Francis as Alter Christus. A saint in deacon vestments, humbly performing the lowest church duties, is seated on a shining throne. This is associated with the already mentioned story about the vision of thrones set forth by Thomas Chelansky (2 Cel. 123) and almost literally repeated by Bonaventure (Bon. Leg. Major. VI. 6): one of the monks in an ecstatic state saw a throne in the heaven, more beautiful than all others, and heard a voice announcing that the throne was intended for the humble Francis. Thus, the throne has become a symbolic embodiment of one of the main ideas of Christianity - the triumph of heavenly power over earthly power.

\section{Conclusions}

The symbolism of power is diverse, and it acquires a slightly different meaning with societies' developing: the symbols must accurately indicate the social role of the individual. The heuristic potential of studying the symbolism of power is especially revealed in the interaction of cultures, for example, during the formation of the Hellenistic system of power, the birth of Roman-barbarian kingdoms or the reconquest on the Iberian Peninsula.

In pre-industrial societies, the ceremonies of obtaining power, both real and spiritual, appear as symbols and rituals - crown and similar headdresses and jewelry, clothing of the ruler, performing not only a symbolic, but also a communicative role. 
Of particular importance is the sacralization of the space of power which in early societies is a real sociocultural practice, and later it loses its original functional meaning, being preserved only in the form of traditions of special veneration not only of the personality of the ruler, but also of the physical space in which he exercises his functions.

The symbolism of power is so universal that even in societies with a democratic system, empowerment is personified and transmitted visually as the coronation of a demos, and the gesture of a politician pointing to his head is interpreted by his political opponents as a demand of the crown, that is, a call for vesting of individual authority.

The article presents the most universal components of the images of power that have developed in various societies of Antiquity and the Middle Ages, as well as the specifics of their representation through symbols and signs that make it possible to see the transformation of ideas about power in pre-industrial societies of the West and East.

\section{Acknowledgements}

The work is performed according to the Russian Government Program of Competitive Growth of Kazan Federal University

\section{References}

Abélès, M. (1992). La Vie quotidienne au Parlement européen. Paris, Hachette.

Aurov, O. V. (Ed.). (2017). Theology and Politics. Power, Church and the Text in the Kingdoms of the Visigoths (5th - beginning of the 8th century). Publishing House "Delo".

Beard, M. (2009). The Roman Triumph. Cambridge (Massachusetts); London: Harvard University Press.

Berger, P. L., \& Luckmann, Th. (n.d.). The Social Construction of Reality. A Treatise in the Sociology of Knowledge. London: Penguin Books.

Bonaventura. Legenda Major Sancti Francisci. Retrieved from http://www.documentacatholicaomnia.eu/03d/1221-1274,_Bonaventura,_Legenda_Major_Sancti_Francisci, _LT.pdf

Boytsov, M. A. (2015). Anointing to Reign: from Saul to Staufen et seq. Image and Symbol in the Jewish, Christian and Muslim Traditions. "Indrik".

Claessen, H. J. M. (1986). Kingship in the early state. Bijdragen tot de Taal-, Land-en Volkenkunde, 142(1), 113-129. https://doi.org/10.1163/22134379-90003371

Collins, A. W. (2012). The Royal Costume and Insignia of Alexander the Great. American Journal of Philology, 133(3), 371-402. https://doi.org/10.1353/ajp.2012.0024

Eco, U. (2014). From the Tree to the Labyrinth: Historical Studies on the Sign and Interpretation. Cambridge (Masachusetts); London: Harvard University Press. https://doi.org/10.4159/9780674728165

Fredricksmeyer, E. A. (1997). The Origin of Alexander's Royal Insignia. Transactions of the American Philological Association, 127, 97-109. https://doi.org/10.2307/284388

Gadamer, H.-G. (1990). Gesammelte Werke1: Hermeneutik I Wahrheit und Methode. Grundzüge einer philosophischen Hermeneutik. Tübingen: Mohr.

Geary Patrick, J. (1988). Before France and Germany: The Creation and Transformation of the Merovingian World. Oxford \& New York: Oxford University Press.

Glowacki, K. (2003). A Personification of Demos on a New Attic Document Relief. Hesperia, 72, 447-466. https://doi.org/10.2972/hesp.2003.72.4.447

Gomez-Ruiz, R. (2007). Mozarabs, Hispanics, and the Cross. Maryknoll; N.Y.: Orbis Books.

Hitchcock, R. (2008). Mozarabs in Medieval and Early Modern Spain: Identities and Influences. Aldershot: Ashgate.

Jordanis. De origine actibusque Getarum. Retrieved from http://www.thelatinlibrary.com/iordanes1.html

Knapp, A. (2015). Royal apologetic in the ancient Near East. Atlanta, SBL Press. https://doi.org/10.2307/j.ctt18z4h1f

Lawton, C. L. (1995). Attic document reliefs: art and politics in ancient Athens. Oxford: Clarendon Press.

Olbricht, M. Y. (2015). Ornamenta regia - Regalia of Alexander the Great in 330-323. Problems of History, 
Philology, Culture, (1), 134-143.

Olbrycht, M. J. (2014). The Diadem in the Achaemenid and Hellenistic Periods. Anabasis, 5, 177-187.

Said, E. (1978). Orientalism. New York: Pantheon Books.

The Mozarabs - Their Architecture and Art. P. 1-42. Retrieved from http://www.green-man-ofcercles.org/articles/the_mozarabs_their_architecture_and_art.pdf

Vauchez, A. (2012). Francis of Assisi: the life and afterlife of a medieval saint, translated by Michael F. Cusato. London: Yale University Press.

Wood, I. (2014). The Merovingian Kingdoms 450-751. Routledge. https://doi.org/10.4324/9781315836539

\section{Copyrights}

Copyright for this article is retained by the author(s), with first publication rights granted to the journal.

This is an open-access article distributed under the terms and conditions of the Creative Commons Attribution license (http://creativecommons.org/licenses/by/4.0/). 